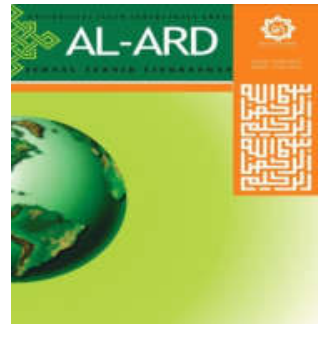

AL-ARD: JURNAL TEKNIK LINGKUNGAN

Vol. 4 No. 1- September 2018 (xx-xx)

AL-ARD

JURNAL

TEKNIK LINGKUNGAN

www.al-ard.uinsby.ac.id

\title{
IMPROVEMENT OF AWARENESS AND ASPECT OF COMMUNITY PARTICIPATION IN ENVIRONMENTAL MANAGEMENT AND CLIMATE CHANGE ADAPTATION BY ECO-MOSQUE
}

\author{
Shinfi Wazna Auvaria \\ UIN Sunan Ampel, Surabaya, Indonesia \\ shinfiwazna@uinsby.ac.id
}

\begin{abstract}
Climate change and environmental pollution are some of the current environmental issues of global concern. One in six people died in 2015 due to environmental pollution. Climate change that occurs can be seen from the recent number of rainy season shift and extreme natural disasters. IPCC's fifth Assessment report says that there are $95 \%$ chance of human activity in the last 50 years is the trigger of climate change. Some means to achieve SDG's targets and solving environmental problems are increasing awareness and aspects of community participation in the settlement, including adaptation and mitigation of climate change. Some countries with a majority of the population of Muslims, there is Authentic Islamic Environmental Movement. One of the adapted program is EcoMosque as one of the ways to increase awareness and to increase aspects of community participation in overcoming environmental problems in Indonesia. EcoMosque is very possible to be done in Indonesia because supported by the majority of Islamic's population which is very potential in the implementation.
\end{abstract}

Keywords: SDG's, community participation, adaptation, mitigation, climate change, eco-mosque

\begin{abstract}
Abstrak
Perubahan iklim dan pencemaran lingkungan merupakan beberapa isu lingkungan terkini yang menjadi perhatian global. Tercatat pada Tahun 2015, satu dari enam orang di dunia meninggal akibat pencemaran lingkungan. Perubahan iklim yang terjadi dapat dilihat dari jumlah pergantian musim hujan dan bencana alam ekstrem yang terjadi saat ini. Laporan penilaian kelima IPCC menyatakan adanya 95\% kemungkinan aktivitas manusia dalam 50 Tahun terakhir merupakan pemicu terjadinya perubahan iklim. Beberapa cara untuk mencapai target Sustainable Development Goal (SDG's) dan mengurangi masalah lingkungan adalah dengan meningkatkan kesadaran serta aspek partisipasi atau peran serta masyarakat dalam mengatasi permasalahan, termasuk adaptasi dan mitigasi perubahan iklim. Beberapa negara dengan mayoritas penduduk muslim telah melakukan gerakan untuk perbaikan lingkungan berupa Authentic Islamic Environmental Movement. Salah satu gerakan yang dapat diadaptasi adalah Eco-Masjid sebagai salah satu cara untuk meningkatakan kesadaran dan meningkatakan aspek partisispasi masyarakat dalam mengatasi masalah lingkungan di Indonesia. Pelakasanaan Eco-Mosque sangat memungkinkan di Indonesia karena dukungan jumlah populasi muslim yang sangat berpotensi untuk implementasinya.

Kata Kunci: SDG's, peran serta masyarakat, adaptasi, mitigasi, perubahan iklim, eco-masjid
\end{abstract}

\section{PENDAHULUAN}

Permasalahan lingkungan yang sedang penjadi perhatian Global (termasuk di Indonesia), setelah permasalahan energi, adalah pencemaran lingkungan dan masalah perubahan iklim (Guntoro, 2017). Pencemaran lingkungan yang terjadi meliputi pencemaran air, udara, dan tanah. Dampak dari pencemaran terkait dengan sanitasi lingkungan dari aspek penyediaan air bersih p-ISSN: 2460-8815 , e-ISSN: 2549-1652 dan pengelolaan limbah (cair dan padat/sampah) adalah tingginya tingkat kematian. Pada Tahun 2015, tingkat kematian akibat pencemaran lingkungan yang dihimpun dari jurnal medis The Lancet sebanyak satu dari enam orang di Dunia (Indra, 2017). Permasalahan pencemaran lingkungan di Indonesia menjadi pertimbangan pemerintah dalam capaian dan target pembangunan sanitasi di Indonesia. Sanitasi lingkungan yang 
dimaksud meliputi penyediaan air bersih yang sudah tidak tercemar, persampahan yang memadai, pengolahan dan penyaluran air limbah termasuk drainase, dan bebas kumuh di Indonesia. Agenda Sustainable Development Goal (SDG's) yang merupakan pengganti Millenium Development Goal's memiliki pandangan yang holistik dan multidimensi tentang pembangunan, dengan agenda 2030 untuk mengatasi berbagai tantangan yang dihadapi manusia dalam penanganan kesejahteraan manusia, kemakmuran ekonomi, dan perlindungan terhadap lingkungan (Pradhan, et.al., 2017) . Pelaksanaan pengelolaan lingkungan di Indonesia, dilakukan melalui Program Sanitasi 100-0-100. Program 5 Tahun yang dimulai Tahun 2015 dan berakhir pada Tahun 2019 ini mempunyai target akses air minum untuk masyarakat tercapai 100\%, $0 \%$ kawasan kumuh, dan $100 \%$ sanitasi lingkungan terpenuhi. Permasalahan lingkungan lain, yakni perubahan iklim, menjadi perhatian dunia karena telah berdampak pada banyak aspek seperti pembangunan sosial ekonomi di Indonesia (Ridwan dan Chazanah, 2013). Selain dampak sosial, ekonomi, dan kesehatan, perubahan iklim juga berdampak pada bidang pertanian (Rasmiayati dan Djuwendah, 2015).

Intergovernmental Panel on Climate Change (IPCC), pada assessment report kelimanya menyebutkan bahwa terdapat 95\% kemungkinan aktivitas manusia pada 50 tahun terakhir adalah pemicu perubahan iklim. Salah satu cara untuk mengatasi permasalahan lingkungan yang ada saat ini adalah dengan meningkatkan awareness atau kewasapadaan dan aspek peran serta masyarakat dalam penyelesaiannya, termasuk adaptasi dan mitigasi terhadap perubahan iklim. Peningkatan awareness dimaksudkan, agar masyarakat paling tidak mengetahui dan memahami tentang permasalahan lingkungan yang sedang terjadi. Aspek peran serta masyarakat dalam penyelesaian beberapa masalah lingkungan telah banyak dikaji, dikembangkan, dan berhasil diterapkan, seperti halnya untuk mengatasi masalah persampahan dengan pengembangan Tempat Pengolahan Sampah Terpadu (TPST) dan bank sampah. Dari segi hukum, peran serta masyarakat juga menjadi sesuatu yang mutlak dalam kerangka menciptakan lingkungan hidup yang sehat (Sabardi, 2014).

Pada beberapa negara-negara dengan mayoritas penduduk beragama Islam seperti Turki, Iran, Indonesia,dan Malaysia, sudah p-ISSN: 2460-8815, e-ISSN: 2549-1652 terdapat garakan "Authentic Islamic Environmental Movement" (Nasr dalam Wihbey, 2012). Mengingat juga bahwa islam adalah agama yang penuh kasih, pentingnya menjaga lingkungan menjadi salah satu awarness yang harus ditanamkan pada setiap muslim. EcoMasjid menjadi salah satu pilihan cara untuk peningkatan awareness dan peningkatan aspek peran serta masyakat dalam mengatasi permasalahan lingkungan di Indonesia. Indonesia sebagai negara dengan mayoritas penduduk beragama Islam sangat berpotensi dalam pelaksanaan EcoMasjid. Potensi ini didukung dengan jumlah masjid yang cukup besar di Indonesia yang mencapai jumlah 800.000 masjid.

\section{METODE PENELITIAN}

Jenis data yang digunakan penulis dalam penelitian ini adalah data sekunder yang diperoleh dari beberapa jurnal dan literaturliteratur lain terkait penelitian. Data-data yang telah diperoleh dianalisis dengan metode analisis deskriptif.

\section{HASIL DAN PEMBAHASAN Pengelolaan Lingkungan}

Pengelolaan lingkungan hidup dalam UU No.32 Tahun 2009 tentang Perlindungan dan Pengelolaan Lingkungan Hidup, adalah upaya sistematis dan terpadu yang dilakukan dilakukan untuk melestarikan fungsi lingkungan hidup dan mencegah terjadinya pencemaran dan/atau kerusakan lingkungan hidup yang meliputi perencanaan, pemanfaatan, pengendalian, pemeliharaan, pengawasan, dan penegakan hukum. Masih menurut UU yang sama, beberapa tujuan dari perlindungan dan pengelolaan lingkungan hidup adalah:

a. Melindungi wilayah Negara Kesatuan Republik Indonesia dari pencemaran dan/atau kerusakan lingkungan hidup

b. Menjamin keselamatan, kesehatan, dan kehidupan manusia

c. Menjamin kelangsungan kehidupan makhluk hidup dan kelestarian ekosistem

d. Menjaga kelestarian fungsi lingkungan hidup

e. Mencapai keserasian, keselarasan, dan keseimbangan lingkungan hidup

f. Mengendalikan pemanfaatan sumber daya alam secara bijaksana

g. Mewujudkan pembangunan berkelanjutan

h. Mengantisipasi isu lingkungan global. 
Sesuai dengan tujuan pengelolaan lingkungan hidup untuk melindungi warga negara (masyarakat) dari pencemaran lingkungan dan menjamin keselamatan dan kesehatan manusia, beberapa aspek sanitasi lingkungan perlu ditingkatkan dengan partisipasi aktif dari masyarakat.

Pelaksanaan pengelolaan lingkungan juga disesuaikan dengan agenda Sustainable Development Goal (SDG's), yang mempunya target untuk mengentaskan kemiskinan, mencapai kesetaraan, dan mengatasi perubahan iklim (Ishartono dan Raharjo,2016). Program pemerintah yang mendukung pencapaian target SDG's adalah Sanitasi 100-0-100. Sanitasi lingkungan dengan partisipasi aktif masyarakat sesuai dengan program pemerintah untuk memenuhi capaian dan target pembangunan sanitasi di Indonesia. Pelibatan masyakat dalam pelaksanaan pengelolaan lingkungan dengan peningkatan sanitasi dilaksanakan pada penyediaan air bersih/air minum, air limbah, persampahan, dan drainase. Dari data yang disampaikan Direktorat Pengembangan Penyehatan Lingkungan Permukiman yang disampaikan pada sosialisasi penyusunan RP2KPKP di Denpasar pada Tahun 2016, pada Tahun 2014, pengolahan air limbah di Indonesia masih $62,14 \%$, aspek persampahan 86,73\%, dan drainase 57,9\%. Sedangkan target dari pemerintah untuk ketiga aspek tersebut dapat mencapai $100 \%$ pelayanan pada Tahun 2019.

Salah satu upaya pendekatan dalam pembangunan sanitasi 2015-2019 adalah dengan pembangunan berbasis masyarakat dengan program SANIMAS, PAMSIMAS, dan TPS 3R berbasis masyarakat.

\section{Awareness Dan Adaptasi Perubahan Iklim}

Isu perubahan iklim dalam pembangunan menjadi salah satu perhatian khusus. Gagasan mengaitkan agenda perubahan iklim dengan target SDG's sangat relevan, dan telah banyak diadopsi oleh sebagian besar negara-negara di Dunia (Wijaya, et.al., 2018). Perubahan iklim didefinisikan pola perubahan iklim yang mulai terjadi di pertengahan hingga akhir abad 20, yang diakibatkan oleh peningkatan Karbondioksida (CO2) di atmosfer (Lineman, et.al., 2015). Peningkatan CO2 sebagian besar diakibatkan oleh aktifitas manusia seperti penggunaan bahan bahan bakar fosil, kegiatan industri, dll. Sedangkan menurut UU No.32 Tahun 2009 Tentang Perlindungan dan Pengelolaan Lingkungan Hidup, perubahan iklim adalah berubahnya iklim yang diakibatkan langsung atau tidak langsung oleh aktivitas manusia sehingga menyebabkan perubahan komposisi atmosfir secara global dan selain itu juga berupa perubahan variabilitas iklim alamiah yang teramati pada kurun waktu yang dapat dibandingkan.

Perubahan iklim ditandai dengan kenaikan level air laut, peningkatan suhu global, warming ocean, peleburan es di kutub, dan bencana alam yang cukup ekstrim (banjir, kekeringan), dan bergesernya musim hujan (Rasmikayati dan Djuwendah, 2014; IPCC, 2018). IPCC pada assessment report kelima juga menyebutkan bahwa emisi yang disebabkan oleh aktivitas manusia, seperti Gas Rumah Kaca, adalah yang terbesar dalam sejarah. Perubahan iklim yang terjadi saat ini telah berdampak pada banyak aspek kehidupan manusia dan sistem lingkungan. Berikut adalah beberapa bukti dari adanya Perubahan Iklim yang dikemukaan oleh The National Aeronautics and Space Administration (NASA, 2018):

1. Suhu rata-rata permukaan bumi mengalami peningkatan berkisar 2 derajat Fahrenheit (1,1 derajat Celcius) sejak akhir abad 19

2. Pemanasan suhu di lautan, karena sekitar 700meter dari atas/permukaan laut, mengalami pemanasan 0,3 derajat Fahrenheit sejak Tahun 1969

3. Lapisan es di Greenland dan Antartika telah mengalami pencairan. Data dari NASA's Gravity Recovery and Climate Experiment menunjukkan pada Greenland, telah terkikis lapisan esnya sebanyak 150-250 kilometer kubik pada Tahun 2002-2006. Sedangkan di Antartika sebanyak 152 kilometer kubik es telah mencair pada Tahun 2002-2005

4. Kenaikan muka air laut pada Tahun 1880 hingga saat ini dilaporkan meningkat sebanyak $20 \mathrm{~cm}$

5. Bencana alam yang cukup ekstrem, seperti jumlah kenaikan suhu bumi yang meningkat di Amerika,dan catatan temperatur terendah yang berkurang. Peningkatan jumlah intensitas air hujan yang meningkatkan banjir besar, kekeringan akibat cuasca ekstrem, dsb.

Perlunya adaptasi terhadap perubahan iklim menjadi salah satu tujuan edukasi dan peningkatan awareness ke masyarakat. Adaptasi perubahan iklim sendiri menurut Lembaran Negara RI Tahun 2009 No.140 sebagai penjelasan UU No.32 Tahun 2009 
tentang Perlindungan Pengelolaan Lingkungan Hidup, adalah upaya yang dilakukan untuk meningkatkan kemampuan dalam menyesuaikan diri terhadap perubahan iklim, termasuk keragaman iklim dan kejadian iklim ekstrim sehingga potensi kerusakan akibat perubahan iklim berkurang, peluang yang ditimbulkan oleh perubahan iklim dapat dimanfaatkan, dan konsekuensi yang timbul akibat perubahan iklim dapat diatasi.

Adaptasi perubahan iklim sangat penting untuk mengurangi risiko dan dampak yang ditimbulkan terhadap manusia dan lingkungan. Bentuk adapatasi perubahan iklim dapat dilakukan dengan sebuah manajemen lingkungan yang melibatkan peran serta semua elemen masyarakat. Pelibatan peran serta masyarakat diawali dengan peningkatan kesadaran akan pentingnya pengelolaan lingkungan dan adaptasi terhadap perubahan iklim yang sedang terjadi saat ini.

\section{Ecomasjid}

Peningkatan kesadaran dan peran serta masyarakat dalam pengelolaan lingkungan dan adaptasi perubahan iklim dapat dilakukan dengan beberapa cara. Salah satu pendekatan yang paling mungkin dilakukan di Indonesia, yang mayoritas penduduknya muslim, adalah dengan EcoMasjid.

Pada Tahun 2017, Dewan Masjid Indonesia telah meluncurkan program EcoMasjid yang berkesinambungan dengan Lembaga Pemuliaan Lingkungan Hidup dan Sumber Daya Alam Majelis Ulama Indonesia untuk mengatasi permasalahan lingkungan, terutama yang diakibatkan oleh aktivitas manusia, termasuk krisis moral yang terjadi. Perbaikan moral dengan pengingkatan kesadaran masyarakat akan pengelolaan lingkungan melalui media agama/dakwah dengan EcoMasjid sangat diharapkan dapat diterapkan pada setiap kalangan masyarakat. Harapan inicukup rasional, mengingat jumlah masjid di Indonesia yang mencapai 800.000 masjid, dan tersebar di seluruh pelosok Indonesia.

Pengertian Ecomasjid yang dikutip dari laman ecomasjid.id menyebutkan bahwa ecomasjid merupakan sebuah tempat beribadah tetap/permanen yang mempunyai kepedulian terhadap hubungan timbal balik antar makhluk hidup dan lingkungannya. Sedangkan program EcoMasjid yang digagas oleh pemerintah melalui Lembaga Pemuliaan Lingkungan Hidup (PLH) dan Sumber Daya Alam (SDA) Majelis Ulama Indonesia memiliki p-ISSN: 2460-8815, e-ISSN: 2549-1652 pengetian sebagai sebuah program pengelolaan masjid yang berkelanjutan melalui aktivitas pemeliharaan lingkungan hidup dan sumber daya alam untuk peningkatan afektifitas dakwah lisan dan aksi nyata yang terukur. Halini untuk menegaskan bahwa Islam adalah agama yang membawa rahmad bagi seluruh alam semesta (MUILPLHSDA, 2017).

Dari beberapa penelitian yang menyebutkan pencemaran dan perubahan iklim adalah akibat dari aktivitas manusia, dapat disimpulkan bahwa perubahan perilaku dengan peningkatan awareness dan peran serta/partisipasi masyarakat mempunyai peran penting untuk mengatasi permasalahan lingkungan. EcoMasjid menjadi instrumen penting, terutama di negara dengan mayoritas penduduk beragama Islam. Karena dengan pondasi Agama, peningkatan awareness tentang lingkungan dan perubahan iklim dapat diaplikasikan dalam kegiatan seharihari sebagai bentuk ibadah dengan mencintai, menjaga, dan memelihara ciptaan Allah.

Kegiatan memajukan masjid dalam konteks ecomasjid tidak bisa hanya dengan ceramah atau penyuluhan semata di dalam masjid. Perlu beberapa aksi nyata untuk membangun kemandirian umat dalam menghadapi ancaman kelangkaan air dan energi, pengelolaan lingkungan, dan kegiatan adaptasi perubahan iklim lainnya.

\section{Instrumen Eco Masjid untuk Peningkatan Awareness dan Aspek Peran Serta Masyarakat}

Peningkatan awareness dan aspek peran serta masyarakat dengan instrumen ecomasjid telah diaplikasikan di beberapa negara. Tidak hanya negara dengan mayoritas penduduk muslim, tetapi juga berkembang di negara dengan minoritas penduduk muslim. Jerman, Inggris, dan beberapa negara bagian di Amerika telah menggunakan instrumen Ecomasjid untuk peningkatan kesadaran tentang lingkungan dan adaptasi perubahan iklim.

Pengembangan fungsi masjid ini diharapkan dapat menjadikan masjid sebagai pusat kegiatan masyarakat (Fala dan Kharismawan, 2016). Kegiatan masyarakat yang dilakukan dengan membuat dan melaksanakan program dan perancanaan yang berkaitan dengan kegiatan dan atau sarana prasarana masjid. Dengan ecomasjid, diharapkan masjid dapat mempunyai dampak positif terhadap komunitas dan lingkungan. 
Program dan cara yang dapat dilakukan dengan instrumen ecomasjid diantaranya dengan:

1. Mengaplikasikan langsung pengelolaan lingkungan ramah lingkungan pada bangunan masjid. Beberapa aplikasi yang dapat dilakukan diantaranya seperti:

a. Energi Terbarukan: komunitas muslim di Norderstedt, Jerman menjadi pionir dalam bidang energi terbarukan,dengan memasang turbin angin di menara masjid (Badat, 2011). Turbin angin dapat dimanfaatkan untuk cadangan energi yang dapat digunakan masjid tanpa harus bergantung pada listrik dari Batu Bara. Selain memasang turbin angin, penyimpanan energi juga dapat dilakukan dengan pemasangan solar cell pada atap masjid dan beberapa lampu penerangan outdoor (bertiang) di halaman sekitar masjid.

b. Hemat Air dan Energi: aplikasi lain seperti pemasangan keran wudlu otomatis yang hemat air. Keran wudlu hemat air ini dapat menghemat penggunaan air dalam berwudlu sebesar $\quad 41,8 \%$ (Agustiawan dan Hadi, 2017). Pemanfaatan lain dengan menggunakan kembali atau daur ulang air bekas wudlu untuk penyiraman tanaman di halaman masjid, seperti telah dilakukan di Masjid Manarul Ilmi ITS Surabaya. Pemenuhan kebutuhan air juga memanfaatkan rainwater harvesting system dan sumur resapan, untuk memanen air hujan sebagai sumber air cadangan dan untuk konservasi air. Rainwater harvesting juga dapat dimanfaat sebagai cadangan air untuk flushing closet.

2. Membuat dan melaksanakan program untuk kegiatan yang berkaitan dengan edukasi untuk peningkatan kesadaran akan pentingnya pengelolaan lingkungan dan adaptasi perubahan iklim, diantaranya dengan:

c. Menjadikan Masjid Sebagai Pusat Edukasi Lingkungan: kegiatan seperti penghijauan dan daur ulang sampah dapat diinisiasi dari masjid. Kegiatan penghijauan meliputi kegiatan menanam tanaman toga, sayur, buah, dan beberapa pohon tingkat tiang untuk penyerapan gas C02. Membuat beberapa kelas edukasi non formal, untuk semua usia dengan tema-tema lingkungan. Salah satu kegiatan kelas edukasi lingkungan dapat diisi kegiatan daur ulang dengan praktek langsung membuat produk seperti membuat tempat mukena, rak sepatu untuk di halaman masjid, dsb. Kegiatankegiatan serupa telah banyak dilakukan di beberapa masjid di negara-negara di eropa, afrika, dan amerika. Di Ethiopia, pada setiap ecomasjid terdapat klub menanam pohon yang mengadakan workshop dan hari menanam pohon sebagai bentuk edukasi ke masyarakat dengan aksi lingkungan (ifees.ecoislam, 2015).

d. Membuat Kebijakan dan Program Terkait Pengelolaan Lingkungan: kebijakan dan program yang ramah lingkungan diantaranya dengan menerapkan kebijakan hari "Berjalan menuju Masjid" dengan dasar hadits "Terdapat pahala di setiap langkah yang diambil untuk menuju masjid". Kebijakan dan program lainnya yang paling penting adalah mewajibkan setiap khutbah, ceramah sesudah waktu shalat, dan kajian-kajian di masjid dengan selalu menyisipkan pesan dan materi lingkungan, seperti pengolahan sampah, hemat energi, konservasi air, dll (Ifees.ecoislam, 2015). Program lain untuk adaptasi perubahan iklim melalui peningkatan partisipasi masyarakat masjid adalah dengan membuat unit/lembaga bank sampah, dan pengolahan sampah dengan komposting. Kebijakan lain terkait penghematan energi adalah dengan kebijakan penggunaan lampu LED dan hanya menggunakannya pada waktu malam/gelap.

Setiap program, kegiatan, kebijakan, dan sarana prasarana ecomasjid akan dapat terlaksana dengan partisipasi aktif masyarakat masjid. Kelas-kelas atau kajian yang dilaksanakan untuk ecomasjid juga mengkaji lingkungan dari AlQur'an dan Hadits, dengan membuka beberapa kelas khusus terutama untuk anak-anak sebagai generasi penerus. Ecomasjid juga memberikan reward dan punishment yang diberikan melalui masjid. Reward bisa dalam bentuk apresiasi untuk 
warga dengan progress pengelolaan lingkungan yang baik. Sedangkan punishment seperti halnya dalam "Maaliki Yaumiddin" QS. Alfatihah (1): 4, diberikan pula kepada masyarakat yang, misalnya, masih membuang sampah sembarangan, atau masih menyalurkan limbah tinja ke badan air, dsb.

\section{KESIMPULAN}

Perubahan iklim merupakan salah satu cara Allah menyampaikan sebuah pesan, tentang tanggung jawab manusia di dunia berkaitan dengan lingkungan. Pentingnya peningkatan awareness dan aspek partisipasi masyarakat dalam pengelolaan lingkungan dan adaptasi perubahan iklim menjadi dasar penting dalam perwujudan ecomasjid.

Ecomasjid dapat menjadikan masjid sebagai pusat studi lingkungan dari tingkat wilayah terkecil seperti di tingkat RT hingga pelosok desa, sehingga diharapkan edukasi lebih mengena dan tepat sasaran. Ecomasjid sendiri selain bentuk instrumen peningkatan kesadaran akan pentingnya pengelolaan lingkungan, juga sebagai bentuk syiar agama Islam yang Rahmatan Lil 'Alamin.

Pelaksanaan ecomasjid di Indonesia memiliki potensi yang sangat besar, mengingat mayoritas penduduk di Indonesia adalah muslim, dengan jumlah masjid mencapai ratusan ribu. Jumlah masjid yang tersebar hingga pelosok desa memungkinkan adanya peningkatan awareness akan pentingnya pengelolaan lingkungan dan adapatasi perubahan iklim di tiap lapisan masyarakat di Indonesia.

\section{DAFTAR PUSTAKA}

Agustiawan, dan Abdul Hadi. 2017. Efisiensi Rancang Bangun Keran Wudhu Otomatis Hemat Air. Seminar Nasional Teknologi Informasi, Komunikasi dan Industri 9. Fakultas Sains dan Teknologi. UIN Sultan Syarif Kasim Riau. Pekanbaru, 18-19 Mei 2017.

Anonim. Program Ecomasjid. http://www.ecomasjid.id/apa-itu-ecomasjid diakses tanggal 31 Mei 2018.

Badat, Bilal. 2011. Eco-mosque is Another Powerful Symbol of Islamic Ingenuity dalamhttps://www.theguardian.com/co mmentisfree/belief/2011/jun/24/ecomosque-wind-turbine diakses tanggal 17 Juli 2018.

Direktorat Pengembangan Penyehatan Lingkungan Permukiman. 2016.
Kebijakan dan Strategi Pengembangan Penyehatan Lingkungan Permukiman dalam Mendukung Penanganan Permukiman Kumuh, disampaikan dalam Sosialisasi Penyusunan RP2KPKP, 20 April 2016, Denpasar.ciptakarya.pu.go.id/.../Tayang an\%20Kumuh\%202016_pplp\%20, diakses tanggal 17 Maret 2017.

Fala, Akbar, dan Kharismawan, Rabbani. 2016. Optimalisasi Fungsi Masjid Pendekatan Superimposisi (Desain Masjid Bulak). Jurnal Sains dan Seni ITS. Vol 5,No.2 (2016).

Guntoro, Joko. 2017. Masalah Lingkungan Hidup di Indonesia dan Dunia Saat Ini dalamhttps://lingkunganhidup.co/masa lah-lingkungan-hidup-di-indonesia-dandunia/.29-Agustus-2017 /diakses 27Maret-2018.

Ifees.ecoislam. 2015. Mosques as Green Project Exemplars dalam http://www.ifees.org.uk/mosques-asgreen-project-exemplars/ diakses tanggal 13 Agustus 2018.

Lineman, M., Do,Y, Kim,JY, Joo, G-J. 2015. Talking about Climate Change and Global Warming. Journal PLoS ONE, Vol.10,No.9 September, (United Kingdom: Hayley J.Fowler, Newcastle University:2015).

Indra, Rahman. 2017. Studi:Polusi Penyebab Kematian Terbesar di Dunia dalamhttps://www.cnnindonesia.com/g aya-hidup/20171020152128-255-

249807/studi-polusi-penyebab-

kematian-terbesar-di-dunia, 20Oktober-2017/diakses 31-Maret-2018.

IPCC, Fifth Assessment Report, (United Nation: 2014).

Ishartono, I., \& Raharjo, S. T. 2016. Sustainable Development Goals (SDGs) dan Pengentasan Kemiskinan. SHARE : Social Work Journal, 6(2), 154-272. https://doi.org/10.24198/swj.v6i2.220

MUI-LPLHSDA. 2017. Masjid Ramah Lingkungan-ecoMasjid. https://muilplhsda.org/program-nasional-masjidramah-lingkungan-ecomasjid/ diakses tanggal 31 Mei 2018.

National Aeronautics and Space Administration (NASA). 2018. Climate Change: How Do We Know?, dalam https://climate.nasa.gov/evidence/, 28 Maret 2018/ diakses 29 Maret 2018.

Pradhan, P., Costa, L., Rybski,D., Lucht, W., \& Kropp, P.J. 2017. A Systematic Study of 
Sustainable Development Goal (SDG) Interactions. Earth's Future, Vol 5 Issue 11. November 2017 Pages 1169-1179.

Ridwan, dan Chazanah, Nurul.2013. Penanganan Dampak Perubahan Iklim Global pada Bidang Perkeretaapian Melalui Pendekatan Mitigasi dan Adaptasi. Jurnal Teknik Sipil Jurnal Teoretis dan Terapan Bidang Rekayasa Sipil, Vol. 20, No.20 Agustus, (Bandung:ITB, 2013),1.

Rasmikayati, Elly dan Djuwendah, Endah. 2015. Dampak Perubahan Iklim Terhadap Perilaku dan Pendapatan Petani. Jurnal Manusia dan Lingkungan, Vol.22,No.3, November (Yogyakarta:UGM,2015) 372-379.

Sabardi. 2014. Peran Serta Masyarakat dalam Pengelolaan Lingkungan Hidup Menurut Undang-Undang Nomor 32 Tahun 2009 Tentang Perlindungan dan Pengelolaan Lingkungan Hidup. Yustisia Jurnal Hukum, Vol.3, No.1, Januari-April (Surakarta:UNS, 2014).68.

Undang-Undang Republik Indonesia No.32 Tahun 2009. Perlindungan dan Pengelolaan Lingkungan Hidup.

Wihbey, John. 2012. Green Muslims, EcoIslam and Evolving Climate Change Consciousness.https://www.yaleclimate connections.org/2012/04/greenmuslims-eco-islam-and-evolvingclimate-change-consciousness/, 4 April 2012/ diakses 16 Agustus 2017.

Wijaya, A., Chrysolite, H., \& Shalihah, H. 2018. Mengatasi pemanasan global dapat mempercepat tercapainya SDG di Indonesia. Diakses 30 june 2018, fromhttp://theconversation.com/meng atasi-pemanasan-global-dapatmempercepat-tercapainya-sdg-diindonesia-94203/ 